\title{
Glass Ceilings, Glass Escalators and Revolving Doors
}

\section{Comparing Gendered Occupational Trajectories and the Upward Mobility of Men and Women in West Germany}

\author{
Lydia Malin and Ramsey Wise
}

\section{Introduction}

Several studies have demonstrated a female disadvantage with regards to upward occupational mobility due to structural barriers commonly referred to as "glass ceilings" (Maume 1999a; Reskin 1993; Cotter et al. 2001). These barriers are often attributed to prejudice based on gender stereotypes of social roles (e.g. Eagly 2003; Eagly and Karau 2002) as well as discrimination and stigmatization, particularly of mothers (Aisenbrey et al. 2009; Benard and Correll 2010; Budig et al. 2012; England 2005; Gangl and Ziefle 2009). In addition to studies of a female disadvantage in male-typical occupations, Williams (1992) demonstrated men to experience more career opportunities for promotion compared to women in female-typical occupations (i.e. "the glass escalator" effect).

We provide a holistic description of how gender effects on upward occupational mobility vary by gender-typical occupations. ${ }^{1}$ To this end, much of the empirical research concerning gender differences in career advancement has focused on either

\footnotetext{
${ }^{1}$ The gender-typicality of occupations is defined as follows: occupations with more than $70 \%$ of female employees are defined as female-typical, occupations with 30 up to $70 \%$ women as mixed, and occupations with less than $30 \%$ of female employees subject to social insurance contributions as male-typical or henceforth referred to as female, mixed and male.
}

L. Malin $(\triangle)$

University of Cologne, Cologne, Germany

e-mail:malin@iwkoeln.de

R. Wise

University of Bremen, Bremen, Germany

e-mail: rwise@bigsss.uni-bremen.de

G. Ritschard, M. Studer (eds.), Sequence Analysis and Related Approaches, 
the American (e.g. Maume 1999a; Budig 2002) or Scandinavian context (e.g. Hultin 2003). For Germany, there are many studies on gendered occupational careers (for the motherhood penalty in downward occupational mobility see e.g. Aisenbrey et al. 2009, for gender-pay gap see e.g. Brückner 2004, for gender inequalities in occupational prestige see e.g. Härkönen et al. 2016, or Manzoni et al. 2014), on the importance of partner resources for occupational promotion (Bröckel et al. 2015) or the gender pay gap in managerial positions (Busch and Holst 2009; Holst 2006).

Only one study controls for gender-typical occupational differences. In analyzing the gender gap in attaining a first management position, Ochsenfeld (2012) uses field of study as measurement of gender-typicality of occupation. However, this study only considers access into leadership, but does not consider a potential revolving door mechanism, whereby access to leadership position may not guarantee remaining in this position. Similarly, Dämmrich and Blossfeld (2017) recently investigated a female disadvantage in holding a supervisory position from a country comparative perspective. For Germany they found that women working in male occupations do not significantly differ from men in holding supervisory positions. Although they accounted for horizontal gender segregation, we contribute to the literature by taking into account two dimensions of a potential male advantage in upward occupational mobility: (1) accessibility and (2) the likelihood to stay in or to leave a leadership position.

Subsequently, we investigate to what extent glass ceiling and glass escalator effects are indeed evident in West Germany. More precisely, we ask: (1) Do men demonstrate an advantage regarding access to and staying in leadership? (2) To what extent does occupational segregation explain gender differences in upward mobility? (3) Do gender effects vary across occupations?

To answer these research questions, the West German case is of special interest. Despite recent changes in work family policies in Germany that are work-family oriented, our observation time is better reflected in the long-standing tradition of the male breadwinner and female caregiver household division of labor that has reinforced gender norms over time (Trappe et al. 2015). Moreover, this dynamic has been further strengthened by strong horizontal sex segregation, whereby women typically belong to different occupations than men (Jacob et al. 2013).

Previous research has linked this selection process of men and women into gender-typical jobs to explain gender differences in vertical sex segregation (Dämmrich and Blossfeld 2017; Charles 2003). Others have investigated whether men and women are more advantaged in gender-typical or gender-atypical occupations. Some have found evidence of a "glass ceiling" effect for women in male occupations (Reskin and Roos 1990), but a "glass escalator" effect for men in female occupations (Williams 1992; Maume 1999b; Cotter et al. 2001). To this end, we aim to demonstrate to what extent these gender differences are attributed to horizontal sex segregation in West Germany.

Section 2 presents our hypotheses, which are derived from theory and empirical evidence. In Sect. 3, we discuss our sample using data from the German National Educational Panel Study (NEPS). As this provides monthly employment histories, we use discrete-time hazard models to estimate the influence of gender, gender- 
typical occupations and the interaction of both on the probability to enter and to stay in leadership positions. The results of the analyses are provided in Sect. 4. Section 5 discusses results and avenues for further research.

\section{Theoretical Considerations and Hypotheses}

The expected male advantage regarding upward occupational mobility denotes two dimensions: (1) a higher probability to enter leadership positions and (2) a higher probability to stay in leadership positions. This assumption receives support from several theoretical approaches discussed in more detail in the following sections. As we aim to also disentangle the main and interaction effects between gender and occupational gender composition, we have organized theoretical considerations by (1) gender effects, (2) gender compositional effects and (3) how gender effects vary across female, mixed and male occupations.

\subsection{Gender and Upward Occupational Mobility}

Despite some improvements in female educational attainment and labor market participation in younger cohorts, women often fail to attain leadership positions, which are dominated by men (e.g. Eagly 2003). Several theories have been put forward to explain the well-documented male advantage in upward mobility. For example, the "glass ceiling" effect refers to structural barriers that women face when rising up the career ladder. Consequently, the male advantage is stronger at the top of the status hierarchy than at lower levels (Cotter et al. 2001).

Albeit a highly complex phenomenon, many sociologists have emphasized how gender norms contribute to prejudice against women with regards to obtaining promotions during the career (e.g. Ridgeway 2001; Ridgeway and Correll 2004; Williams 1992). For example, "role congruity theory" argues that women hold fewer leadership positions because these positions are typically associated with characteristics attributed to men (Eagly and Karau 2002). The perceived incongruity between traditional female role characteristics and leadership roles thus stigmatizes women as less appropriate for leadership. Eagly and Karau (2002) further observed that women exhibiting male characteristics are also stigmatized and devalued in comparison to their male counterparts (England et al. 1994; Ridgeway 2001), despite being more congruent with leadership characteristics. Therefore, the male advantage is not only observed when entering leadership, but also over the occupational trajectories of men and women. Based on these theoretical considerations, we hypothesize: 
- H1a: Men are more likely to enter a leadership position compared to women, irrespective of the gender composition of the respective occupation held.

- H1b: Men are less likely to drop out of leadership positions compared to women, irrespective of the gender composition of the respective occupation held.

\subsection{Gender Composition and Upward Occupational Mobility}

In additional to gender effects, there are several studies that attribute male advantages in the labor market to occupational sex segregation (e.g. Charles 2003; Ko et al. 2015 for the US; Hultin 2003 for Sweden; Busch 2013 for Germany). However, most of these studies do not take into account the role of labor market segmentation or provide theoretical arguments for differences in the institutional set-up structuring upward mobility in female and male occupations. Because men and women often (self-)select employment in gender-typical occupations, we argue that much of the gender effect can be explained by the different work arrangements of these occupations. For this reason, we are interested in how gender composition influence leadership opportunities regardless of gender.

As an important aspect of mobility research, labor market sociologists have long debated the relationship between labor market segmentation and opportunities for promotion (Edwards 1979; Sengenberger 1987). The growth of large firms is argued to have contributed to labor market segmentation, as hierarchical career ladders were created as a means to secure employee commitment, control the workplace and to reduce sunk costs caused by worker turnover (Farkas and England 1988; Sørensen and Kalleberg 1981). These characteristics, however, largely describe the career trajectories in male occupations.

In contrast, female occupations tend to be primarily aligned either with lowskilled, service sector or semi- and high-skilled, professional occupations. The first type of female occupations exhibits the "revolving doors analogy" comprising low-wage, dead-end jobs that do not provide opportunities for career advancement (Jacobs 1989; Charles and Grusky 2004; Williams 2013). The second type of female occupations is more closely associated with occupational-specific professions (e.g. teaching professions or health professions).

As upward mobility opportunities are highly differentiated across occupations, we expect that female occupations offer fewer opportunities for promotion than male occupations irrespective of the employees' gender. Subsequently, much of the so-called gender effect may actually reflect the selection of women into female occupations that do not offer many opportunities for promotion. Therefore, we hypothesize:

- H2a: Men and women are more likely to hold a leadership position in maletypical occupations and less likely in female-typical ones compared to mixed occupations. 
- H2b: Men and women are less likely to drop out of leadership positions in maletypical occupations and more likely in female-typical ones compared to mixed occupations, irrespective of gender.

\subsection{Gender Composition and Upward Occupational Mobility, by Gender}

In addition to the direct effects of gender and occupational sex segregation, other researchers have argued that the effect of occupational sex segregation may also vary by gender (Dämmrich and Blossfeld 2017; Maume 1999b; Reskin and Roos 1990; Reskin 1993; Cotter et al. 2001). To this end, we lastly inquire whether the male advantage is stronger in male or female occupations. In the following paragraphs, we review several theories that offer polarized viewpoints that we have adopted here as competing hypotheses.

The implicit effect that gender has on the job-matching processes has been extensively demonstrated in relation to statistical discrimination and others means of social closure, i.e. the process by which a group attempts to maintain their position by preventing others from entering (Reskin 1988; Acker 1990; Baron and Newman 1990; Cockburn 1991; Maume 1999a). Women entering male occupations, they not only enter a job queue as job search and job matching theories suggest, but they also enter a "gender queue" whereby employers rank women beneath men due to gender stereotypical belief (Jacobs 1989; Reskin and Roos 1990). For this reason, women are often more disadvantaged when competing for jobs and promotions so that they often are eventually driven out of male occupations due to discrimination or the lack of opportunities (Reskin and Roos 1990).

Kanter's theory of "tokenism" similarly argues that all tokens or minorities are disadvantaged due to heightened visibility, prejudice and gender segregating processes that contribute to social exclusion (Kanter 1977). In line with this theory, men and women are more likely to hold a leadership position in gender-typical occupations than in atypical ones. Respectively, a third hypothesis tested here is:

- H3a: The likelihood to enter a leadership position is higher through gendertypical occupations than gender-atypical ones.

In line with the revolving doors analogy (Jacobs 1989), individuals in gendertypical occupations are less likely to drop out of these occupations. Thus, we further hypothesize that men and women spend more time in leadership in gender-typical occupations:

- H3b: The likelihood to drop out of leadership positions is lower in gender-typical occupations rather than in gender-atypical ones.

In contrast to Kanter's theory of tokenism, however, role congruity theory argues that men have a greater advantage in upward occupational mobility in female 
occupations because they are "only" competing with women whose gender roles are less closely aligned to leadership role characteristics. Similarly, Williams (1992) also argues that men demonstrate a greater advantage in female occupations due to gender stereotyping prejudice in favor of men for leadership positions. Empirical support for this argumentation is given by Dämmrich and Blossfeld (2017). In a country comparative study they investigate women's disadvantage in holding supervisory positions based on the ISCO classification of occupations. Coined as the "glass escalator" effect, this perspective presents competing hypotheses to $\mathrm{H} 3 \mathrm{a}$ and $\mathrm{H} 3 \mathrm{~b}$ :

- H4a: The male advantage in entering a leadership position is highest in female occupations rather than male ones.

- H4b: The male advantage regarding a lower drop out of leadership position is highest in female occupations rather than male ones.

\section{Data and Methods}

\subsection{Data and Sample}

To compare gender and gender compositional effects on upward occupational mobility, we use information on monthly employment biographies from the NEPS, starting cohort 6, (see Blossfeld et al. 2011). This longitudinal dataset contains retrospectively collected employment biographies of individuals born between 1944 and 1986. We use the first four waves available as scientific use file (SUF), carried out from 2009 to 2013. Furthermore, a previous wave of the adult survey was conducted from 2007 to 2008 by the Institute for Employment Research (IAB) under the title, Working and Learning in a Changing World" (ALWA).

We follow individuals from their first significant job for a period of 15 years (180 months). Hence, recent changes in work-family policies are not covered by our data. The first significant job is defined as the first job between the age of 15 and 35 that lasted at least 6 months, which has been similarly used in several previous studies (e.g. Lindemann and Kogan 2013; Smyth 2005). Jobs in preparation for a career, such as internship, traineeship, preparatory service and jobs as student worker are not included. We also excluded respondents who never had a first significant job or have missing information for additional sample-defining characteristics, such as gender or birth date. Furthermore, we excluded individuals born after 1975, as there are too few individuals in the latter birth cohort that adhere to our selection criterion of 180 months of observation following their first significant job. After data preparation and cleaning, our sample consists of 6,402 individual employment 
biographies of which 2,926 are female (45.7\%) and 3,476 are male (54.3\%). We cover the birth cohorts from 1944 to 1955 (32.8\%), from 1956 to 1965 (41.1\%) and from 1966 to $1975(26.1 \%) .^{2}$

\subsection{Variables}

Our primary variables of interest are: (1) upward occupational mobility, (2) the gender of respondent and (3) gender composition of the occupation held at each point in time. In the following we show how these concepts are operationalized.

\subsubsection{Upward Occupational Mobility}

With regards to upward occupational mobility, we are chiefly interested in whether men are more likely, to enter and to stay in leadership compared to women. A leadership position is defined as supervisors and executives, coded with "9" as digit four of the KldB2010 - the German job classification — coding, and coded with 3 or 4 as digit five of KldB2010 (educational requirement level). Following the German statistical office, we also code 71104 (Managing directors and executive board members-highly complex tasks), 71214 (Legislators-highly complex tasks) und 71224 (Senior officials of special interest organizations-highly complex tasks) as leadership positions (Eisenmenger et al. 2014). Regarding this definition 253 of the 1286 occupations are defined as leadership position. However, not all occupations are represented in our sample.

The first outcome "entering leadership position" is defined as first month of an employment in a leadership position after entering the labor market; the second outcome "staying in" versus "leaving" is defined as any state which is not a leadership position after holding one. This is irrespective to job change, i.e. if the individual continues in another leadership position at a different job, the time spent is viewed as leadership continuous. Furthermore, we are not able to control for if the drop out is voluntary or involuntary.

\subsubsection{Gender and Gender-Type of Occupation}

While the interviewers report the respondents' gender, the occupation is surveyed by the open question: "Let's start with the first job you had since $<$ DATE $>$. Please tell me what occupation this was!" The additionally merged gender composition of occupations based on the German Mikrozensus is provided by the German Labor

\footnotetext{
${ }^{2}$ Further descriptive statistics are available here: https://www.researchgate.net/publication/ 320036349_Appendix_only_online.
} 
Agency. As the gender composition of occupations is subject to changes over time, we use the mean share of female employees between the years 2001 and $2011 .^{3}$ The occupations were then categorized as female occupations with more than $70 \%$ of female employees, mixed occupations with 30 up to $70 \%$ women, and male occupations with less than $30 \%$ of female employees subject to social insurance contributions. $^{4}$

\subsection{Methods}

For a first glance we use sequence visualization to describe occupational biographies of men and women. Therefore, we distinguished between nine mutually exclusive states that are based on employment activity, the gender composition of a job held and whether or not the position is in a managerial capacity. These include: (1) manager in female occupation, (2) employee in female occupation (3) manager in mixed occupation, (4) employee in mixed occupation (5) manager in male occupation, (6) employee in male occupation, (7) parental leave, (8) unemployment and (9) education and training. Additionally, we had to include a tenth state for gaps.

In a second step we look at Kaplan-Meier survival functions. To compare the survivor functions between our groups of interest, we are calculating risk sets for each of the 180 month of observation "for being in a leadership" position or "not being in a leadership" position. Firstly, we compare leadership positions held by men and women; secondly, we compare the duration of men and women in leadership position by gender-type of occupation. For both calculations, we use four test statistics: Log-rank, Wilcoxon, Tarone-Ware and Peto-Peto test as recommended by Blossfeld et al. (2012).

In a third step, we use discrete-time event history models, which documents whether, and if so, when events occur (Andreß et al. 2013). We use separate analyses for our two outcome variables of interest: (1) we model the accessibility of leadership for the whole sample and (2) we estimate the probability to leave the leadership position for those who at least once in observation time hold a managerial position. Subsequently, our dependent variables are conditional transition probabilities that individual $i$ will experience the respective event at time $t$, given that the individual hadn't such a transition already in the past. We do not allow for repeating events. Thus, we only consider the first managerial position observed and assume that the dependent variables are dichotomous: " 0 " for the origin state and " 1 " for the destination state. Observations after the first occurrence of the event of interest are no longer part of the analysis.

\footnotetext{
${ }^{3}$ The mean is based on the data from 30th of June as record date for each year to prevent bias of seasonal variation. At that time, the labor market is sturdiest due to stable weather conditions.

${ }^{4}$ With a stricter cutting point of, for example, $80 \%$, there are too few occupations female-typical and with a lower cutting point, such as $60 \%$, occupations that have a nearly balanced gender ratio are also defined as female. However, lower and higher cutting points are used for robustness checks.
} 
As the starting point of our observation period, we identify the first significant job as the point of entry. For the second analysis, we begin with entry into the first leadership position. Although our data are not left censored, we do not know or do not take into account if any of the observed individuals move up into or leave a leadership position after observation time. Thus, we may have right censored data. For this reason we chose this period length of 15 years apart from labor market entry to have a balanced panel data set.

The event history model is estimated using logistic regression, including a time variable as independent covariate, and time-constant as well as time-varying control variables (for more detailed discussion see e.g. Andreß et al. 2013). Furthermore, we use robust standard errors to take into account that month are nested within individuals.

\section{Results}

To first examine the relationship between the probability to enter a leadership position with gender and gender-typical occupations, Sect. 4.1 presents the visualization of occupational biography sequences; in Sect. 4.2 we report results for KaplanMeier Survivor Functions by gender and gender-type of occupation, as well as regression results of event history analysis for entering a leadership position; and finally Sect. 4.3 shows the results for the probability to drop out of leadership for the subsample of those who hold such a position.

\subsection{Leadership Position by Gender and Gender-Typical Occupation}

Based on the KldB2010 measure, only $6.2 \%$ of individuals in the sample hold a leadership position. With regards to gender differences, men appear to have a comparative advantage over women: Only $3.4 \%$ of women hold a leadership position, compared to $9 \%$ of men.

Table 1 shows the duration (Share of Month) in leadership for the subsample of those at least once in leadership. Here again, all gender differences are highly significant and as expected. Women seem to have an advantage in female occupations, while men demonstrate a comparable advantage in mixed and male occupations. Compared to women, men are only more likely to stay in a leadership position in mixed or male- occupations compared to female ones. From these descriptive results, men are more likely to stay in leadership positions in gendertypical occupations. A male advantage in female occupations is not observable.

In Fig. 1, we illustrate the distribution of occupational states by gender for a period of 180 months, following the first significant job. Both men and women are likely to start their employment biography in a gender-typical occupation (62\% for women and $56 \%$ for men). Thereby, at least at labor market entry, men are less gender-typical than women. In addition, the difference between distributions of 
Table 1 Duration in leadership, by gender and occupational gender-type

\begin{tabular}{l|l|l|l|l}
\hline & Women & Men & Total & $\mathrm{Chi}^{2}(\mathrm{Pr})$ \\
\hline Female-typical leadership occupation $(\mathrm{n}=7,686)$ & 58.1 & 49.2 & 56.6 & 0.000 \\
\hline Mixed leadership occupation $(\mathrm{n}=26,288)$ & 62.3 & 89.2 & 78.4 & 0.000 \\
\hline Male-typical leadership occupation $(\mathrm{n}=54,708)$ & 62.6 & 87.7 & 81.6 & 0.000 \\
\hline All occupations $(\mathrm{n}=88,695)$ & 61.5 & 87.3 & 78.5 & 0.000
\end{tabular}

Data: NEPS SUF, SC6 D-5.1.0

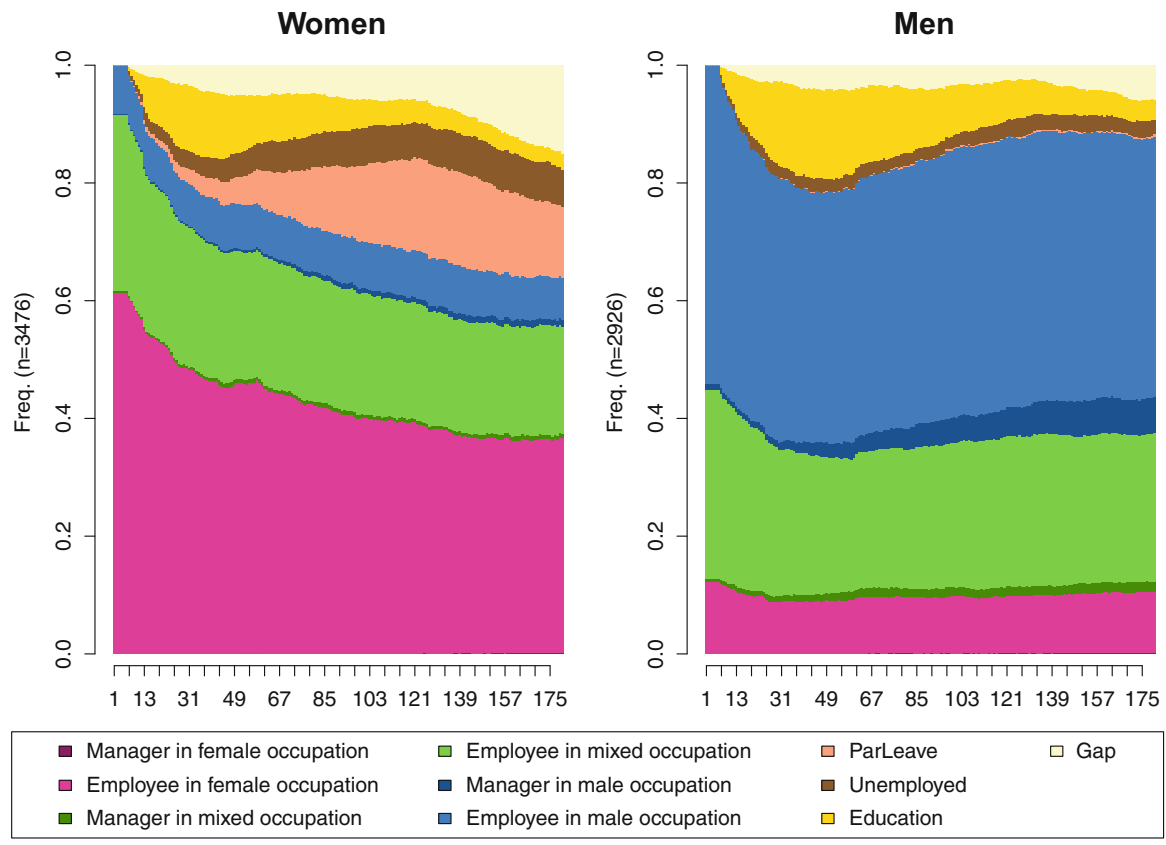

Fig. 1 Sequence distribution plot of occupational states, by gender. Time (horizontal axis) is the number of months following the first significant job. Data: NEPS SUF, SC6 D-5.1.0

occupational states at 1 and 180 months is much more varied for women than it is for men. For example, the share of women working in a female occupation has decreased from 60 to less than $40 \%$ by the end of observation period.

For men, the share employed in a male occupation is nearly the same in month 180 after labor market entry. It should also be noted, however, that roughly $35 \%$ of women have dropped out of the labor market by month 180, presumably accounting for much of the decline of women in female occupations. It is also observable that the gender differences in holding a leadership position, is smallest at the beginning of observation time. As time goes by, more men than women enter leadership positions, especially in male occupations. Regardless of the occupation, however, the highest proportion of leadership positions is observable at the end of observation time, for both men and women. 

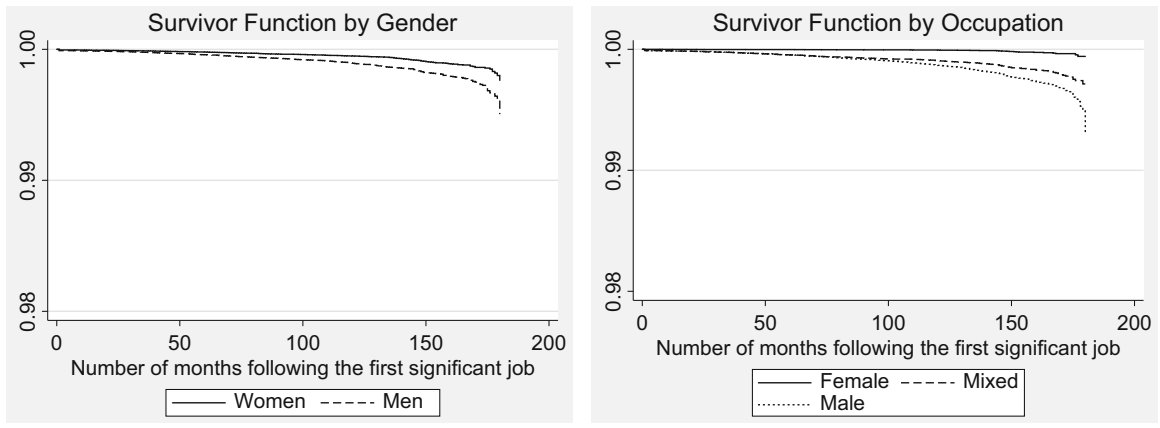

Fig. 2 Access to leadership, by gender and gender-type of occupation. Data: NEPS SUF, SC6 D-5.1.0

\subsection{Access to Leadership Positions}

\subsubsection{Kaplan-Meier Survivor Function}

In this section, we present results from product-limit estimations by gender and gender-type of occupation. This technique has the advantage to be a time-driven estimation technique, meaning that we can demonstrate how differences develop over observation time. The survival curves demonstrated in Fig. 2 reflect the effect of gender - or respective gender-type of occupation - on the probability to "survive" without entering a leadership position. Thus, a "failure" means upward occupational mobility. Subsequently, we applied several test statistics to test whether differences between the groups are significant.

It is obvious that differences are increasing over time, even if they remain relatively small. However, we can observe the expected pattern: men seem to have an advantage to "not survive" without upward mobility. All four applied test statistics confirm that gender differences are highly significant $(p<0.001)$.

Similarly, the survivor functions by gender-type of occupation meet our expectations: Individuals in female occupations are at lower risk to take up a leadership position then individuals in mixed and especially male occupations. All four test statistics again are highly significant $(p<0.001)$. However, none of those survivor functions take into account a possible interaction of gender and gender-composition. Furthermore, it is not controlled for further heterogeneity between the groups. Therefore, we show results of event history models in the following.

\subsubsection{Regression Results}

To disentangle the relevance of gender, gender-type of occupation and their interaction for the upward occupational mobility of men and women, we estimate hierarchical discrete-time event history models with robust standard errors (Table 2). In the first model we only include gender as explanatory variable beside all control 
Table 2 Logistic EHA for access to leadership positions

\begin{tabular}{|c|c|c|c|}
\hline & M1 & M2 & M3 \\
\hline State number per ID & $0.021 * * *$ & $0.020 * * *$ & $0.020 * * *$ \\
\hline Men & $0.792 * * *$ & -0.096 & $0.294 \#$ \\
\hline \multicolumn{4}{|l|}{ Gender-type of occupation (Ref. mixed) } \\
\hline Sextype female & & $-2.213 * * *$ & $-2.329 * * *$ \\
\hline Sextype male & & $0.728 * * *$ & $1.230 * * *$ \\
\hline \multicolumn{4}{|c|}{ Interaction of gender and gender-type of occupation (Ref. mixed) } \\
\hline Men*female occupation & & & $0.793 \#$ \\
\hline Men*male occupation & & & $-0.768 * * *$ \\
\hline \multicolumn{4}{|l|}{ Time constant control variables } \\
\hline \multicolumn{4}{|l|}{ Cohort (Ref. 1944-1955) } \\
\hline $1956-1965$ & -0.022 & -0.122 & -0.113 \\
\hline $1966-1975$ & 0.085 & -0.012 & -0.008 \\
\hline Born in Germany & -0.115 & 0.029 & 0.026 \\
\hline Age at LM Entry & $0.033 *$ & $0.040 * *$ & $0.038 * *$ \\
\hline \multicolumn{4}{|c|}{ Educational Degree at LM Entry (Ref. without vocational degree) } \\
\hline With VET & $0.238 \#$ & 0.229 & $0.265 \#$ \\
\hline With higher educational degree & $0.484^{*}$ & 0.381 & 0.394 \\
\hline \multicolumn{4}{|l|}{ Time varying control variables } \\
\hline \multicolumn{4}{|l|}{ Marital status (Ref. single) } \\
\hline Married & $-0.226 \#$ & $-0.222 \#$ & $-0.218 \#$ \\
\hline Divorced & 0.038 & -0.003 & 0.007 \\
\hline Number of children & -0.165 & -0.109 & -0.125 \\
\hline Number of month employed & $-0.028 * * *$ & $-0.028 * * *$ & $-0.028 * * *$ \\
\hline Number of month in parental leave & -0.007 & -0.003 & -0.003 \\
\hline Number of month in unemployment & $-0.014 *$ & $-0.012 \#$ & -0.012 \\
\hline Number of month in further education & -0.006 & -0.004 & -0.005 \\
\hline Employed as public official & $-1.281 * * *$ & $-0.849 *$ & $-0.937 * *$ \\
\hline Selfemployed & 0.118 & -0.372 & -0.487 \\
\hline Constant & $-8.465 * * *$ & $-8.135 * * *$ & $-8.304 * * *$ \\
\hline $\mathrm{N}$ & 836474 & 836474 & 836474 \\
\hline Pseudo R-squared & 0.03 & 0.07 & 0.07 \\
\hline AIC & 9253.72 & 8945.95 & 8927.97 \\
\hline BIC & 9474.82 & 9190.33 & 9195.62 \\
\hline
\end{tabular}

Data: NEPS SUF, SC6 D-5.1.0

$\# p<0.1 ; * p<0.05 ; * * p<0.001 ; * * * p<0.001$

variables; in model 2 we add the gender-type of occupation and model 3 contain both plus their interaction. In this way, Likelihood-Ratio tests can be used additionally to the Akaike Information Criterion (AIC) and Bayesian Information Criterion (BIC) to assess the model fit.

The overall model fit measure AIC indicates that model 3 including also the interaction effects is the best model. The BIC measure is slightly lower for M2, but the AIC measurement is more straightforward than the BIC, therefore, the recommended choice if there are contradictory outcomes. Furthermore, model 3 is 
also recommended looking at the LR-Test results: M1-M2 $(p<0.001)$ and M2-M3 $(p<0.001)$.

In line with the results of the Kaplan-Meier survivor curves, the time variable shows a general increase of the conditional transition probability that individual $i$ will experience upward occupational mobility at time $t$, given that the individual hadn't such a transition already in the past. Also the main effects of gender and gender-type of occupation are significant and confirm the results from KaplanMeier estimation. When controlling for gender-typicality of occupation (M2), the male gender has a non-significant, negative effect on the conditional transition probability. However, this can be explained through the missing interaction effect, as the gender effect returns to be significantly positive after the interaction is included. Thus, it can be concluded that the consideration of only one aspect—or both main effects-does not lead to proper estimations.

Our results show that women have a significant disadvantage to enter leadership positions compared to men in all occupations. Thus, we find support for H1a: Men are more likely to enter leadership positions compared to women, irrespective of the gender composition of the respective occupation held. Furthermore, we can support H2a: Men and women are more likely to enter a leadership position in male occupations than in mixed ones and less likely to enter a leadership position in female occupations.

Additionally, we find supporting evidence for H3a from the interaction effect of gender and gender-type of occupation. The effect for men is the sum of the main coefficient of "sextype male" (1.230) plus the interaction for men in male occupations (-0.768), which results in a significant positive effect (0.462). Thus, men are more likely to enter a leadership position through male and mixed rather than female occupations, even if the advantage in male occupations is smaller for men than for women. For women, H3a has to be rejected because they have the highest likelihood to enter leadership in male occupations. This finding is in line with previous research in Germany that found women to be less disadvantaged in male occupations (Dämmrich and Blossfeld 2017). The absence of a strong male advantage in male occupations may in part be explained by unobserved personality traits of women who take up male occupations (e.g. lower risk aversion, career-orientation etc.). However, the disadvantage to enter leadership in female occupations is less pronounced for men, while the advantage in male occupations is smaller for men than for women. Thus, we as well do find support for a male advantage - in form of a smaller disadvantage-compared to women in genderatypical occupations, which supports $\mathrm{H} 4 \mathrm{a}$.

\subsection{Leaving Leadership Positions}

In the following, we restrict our observations to those individuals who already entered a leadership position. We are now interested in a possible male advantage of staying in a leadership position. Like in the previous section, we first report results from survivor analyses and second from event history regression. 

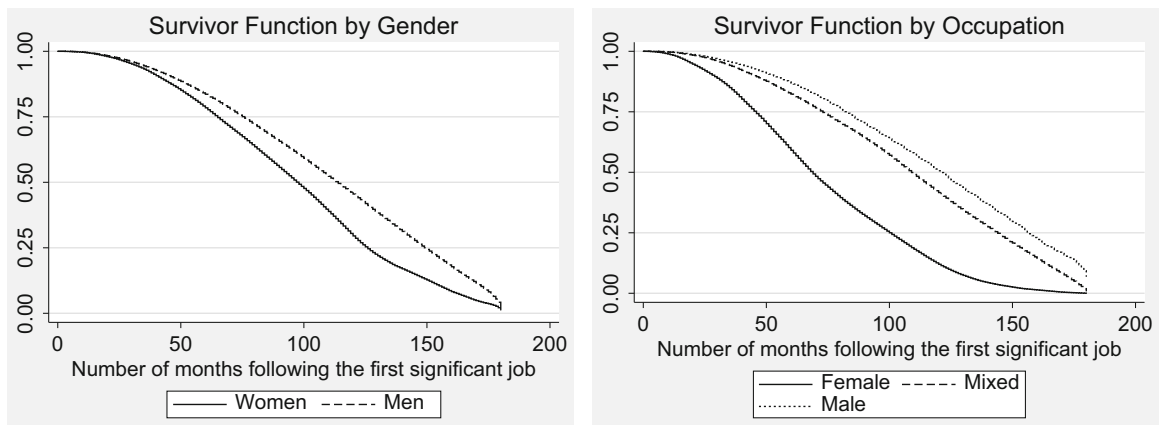

Fig. 3 Dropping out of leadership, by gender and gender-type of occupation. Data: NEPS SUF, SC6 D-5.1.0

\subsubsection{Kaplan-Meier Survivor Function}

The survival curves in Fig. 3 reflect the effect of gender and gender-type of occupation on the probability to "survive" within a leadership position. Subsequently, a "failure" means the dropout of leadership and stands for the revolving doors. With regards to the "survival" in a leadership position, a comparable male advantage is not observable. Following, the applied test statistics do not confirm gender differences, except the Wilcoxon: Log-rank ( $p=0.697)$, Wilcoxon $(p=0.008)$, TaroneWare $(p=0.124)$, Peto-Peto $(p=0.312)$. However, a gender-typicality effect is indeed evident and in line with our expectations. The probability to "survive" within a leadership position is steeply decreasing over the observation period, lowest in female occupations and highest in male ones. All four test statistics are highly significant $(p<0.001)$.

While the descriptive results above indicate a stronger gender effect with nearly no differences between mixed and male-typical leadership positions, the KaplanMeier estimations are inconsistent. Therefore, it is important to have a closer look at the multivariate analysis for a final assessment of results.

\subsubsection{Regression Results}

The event of interest for the following event history analysis is "dropping out of leadership" and refers to the revolving door analogy. The month of entry in the first leadership position is the new starting point of analysis. As in the first analysis, a "failure" or drop out of leadership aligns with sample attrition as an individual that already left leadership is no longer "at risk" of dropping out of leadership.

As in the previous section, results (Table 3) are presented including the model fit measures. Most obvious, the model seems to be more appropriate to estimate the conditional probability of "surviving" within a leadership position. Nearly all coefficients are highly significant. The same is true for the LR-Tests which suggest that the full model including the interaction effects is the most appropriate one (M1M2: $p<0.001$ and M2-M3: $p<0.001)$. AIC and BIC confirm this suggestion. 
Table 3 Logistic EHA for dropping out of a leadership position

\begin{tabular}{|c|c|c|c|}
\hline & L1 & L2 & L3 \\
\hline State number per ID & $0.022 * * *$ & $0.023 * * *$ & $0.023 * * *$ \\
\hline Men & 0.115 & $0.529 \#$ & 0.531 \\
\hline \multicolumn{4}{|l|}{ Gender-type of occupation (Ref. mixed) } \\
\hline Sextype female & & $2.381 * * *$ & $2.952 * * *$ \\
\hline Sextype male & & $-0.573^{*}$ & $-0.849 \#$ \\
\hline \multicolumn{4}{|c|}{ Interaction of gender and gender-type of occupation (Ref. mixed) } \\
\hline Men*female occupation & & & $-1.258 \#$ \\
\hline Men*male occupation & & & 0.33 \\
\hline \multicolumn{4}{|l|}{ Time constant control variables } \\
\hline \multicolumn{4}{|l|}{ Cohort (Ref. 1944-1955) } \\
\hline $1956-1965$ & 0.014 & 0.007 & 0.001 \\
\hline $1966-1975$ & 0.168 & 0.181 & 0.17 \\
\hline Born in Germany & 0.031 & 0.040 & 0.008 \\
\hline Age at LM entry & $-0.087^{*}$ & -0.063 & $-0.067 \#$ \\
\hline \multicolumn{4}{|c|}{ Educational degree at LM entry (Ref. without vocational degree) } \\
\hline With VET & -0.084 & -0.044 & -0.043 \\
\hline With higher educational degree & 0.320 & 0.323 & 0.363 \\
\hline \multicolumn{4}{|l|}{ Time varying control variables } \\
\hline \multicolumn{4}{|l|}{ Marital status (Ref. single) } \\
\hline Married & -0.192 & -0.344 & -0.339 \\
\hline Divorced & $0.800 * *$ & $0.733^{*}$ & $0.757^{*}$ \\
\hline Number of children & $0.611 * *$ & $0.546^{* *}$ & $0.571 * *$ \\
\hline Number of month employed & $-0.006^{*}$ & $-0.007 *$ & $-0.007 * *$ \\
\hline Number of month in parental leave & -0.003 & -0.009 & -0.011 \\
\hline Number of month in unemployment & $0.051 *$ & $0.042 \#$ & $0.042 \#$ \\
\hline Number of month in further education & 0.000 & 0.002 & 0.001 \\
\hline Employed as public official & 0.095 & -0.262 & -0.185 \\
\hline Selfemployed & 0.896 & 0.643 & 0.489 \\
\hline Constant & -0.091 & -0.832 & -0.702 \\
\hline $\mathrm{N}$ & 50892 & 50892 & 50892 \\
\hline Pseudo R-squared & 0.13 & 0.21 & 0.21 \\
\hline AIC & 53654.54 & 48808.49 & 48546.69 \\
\hline BIC & 53813.61 & 48985.24 & 48741.12 \\
\hline
\end{tabular}

Data: NEPS SUF, SC6 D-5.1.0

$\# p<0.1 ; * p<0.05 ; * * p<0.001 ; * * * p<0.001$

The time effect is increasing again in this model, as it was already visible in the Kaplan-Meier curves. In comparison to the results for leadership access, there is no general male advantage for not leaving leadership position. Deviating, the gendereffect indicates a higher transition probability out of leadership for men, but only in M2, without control for the interaction. Thus, we are unable to confirm H1b that men have a general advantage for remaining in a leadership position. 
However, the effect of gender composition is in line with our expectations in $\mathrm{H} 2 \mathrm{~b}$. Women and men do have a higher probability to drop out of leadership in female compared to mixed occupations. The lower probability to drop out of leadership in male occupations compared to mixed ones is only significant for women so that men do not have an advantage in gender-typical occupations. Thus H3b has to be rejected. However, the disadvantage of a higher drop out risk in female occupations is lower for men. Thus, we find empirical support for $\mathrm{H} 4 \mathrm{~b}$, as a male advantage is again visible in form of a lower disadvantage in female occupations.

\section{Discussion}

We have argued that both gender and occupational gender composition have an independent effect on the likelihood to enter and to stay in leadership. To draw support for this claim, we have presented several theoretical perspectives that offer potential explanation for these effects, including gender role congruity theory, labor market segmentation theory, devaluation theory, tokenism theory and social closure theory. Using these arguments, we contribute to the literature by specifically theorizing as to why gender-typical occupations present different opportunity structures for entering leadership positions and how these may vary by gender.

Using sequence visualization, Kaplan-Meier survivor analysis and event history regression, we examined conditional transition probabilities of men and women into and out of leadership positions. Thereby the aim of this paper was to disentangle effects of gender, gender composition of occupations and their interaction.

For access to leadership positions, most of our hypotheses are supported (see Table 4). Men do have a comparable advantage in entering leadership positions. Their likelihood to enter leadership is highest in male occupations. However, their comparable advantage over women is highest in female occupations but in form of a smaller disadvantage. Our analyses support the presence of a male advantage with regards to upward occupational mobility, even when controlling for occupational gender composition (H1a). Additionally, we were able to show the importance of the gender-typicality of occupations. We presented discrete-time event history results for each of the outcome variables. In line with our theoretical expectations, we find that compared to mixed occupations, female-typical occupations have a negative effect on access to leadership, while male-typical occupations have a positive effect (H2a).

A particular surprising result, however, is the interaction effect between the two. In the theoretical section, we presented two competing hypotheses. We hypothesized that leadership access would be higher in gender-typical occupations rather than atypical ones (H3a). We further tested for a glass escalator effect, whereby the male advantage was hypothesized to be stronger in female occupations rather than male ones. We found that the likelihood for leadership access is highest in gender-typical occupations, but this is only the case for men. Moreover, we found support for $\mathrm{H} 4 \mathrm{a}$, although the male-advantage is only evident in form of a smaller disadvantage 
Table 4 Hypotheses and findings

\begin{tabular}{|c|c|c|c|c|}
\hline & $\begin{array}{l}\text { Access to leadership } \\
\text { (a) }\end{array}$ & Finding & $\begin{array}{l}\text { Staying in } \\
\text { leadership (b) }\end{array}$ & Finding \\
\hline H1 & $\begin{array}{l}\text { Men are more likely } \\
\text { to enter a leadership } \\
\text { position compared } \\
\text { to women, } \\
\text { irrespective of the } \\
\text { gender composition } \\
\text { of the respective } \\
\text { occupation held. }\end{array}$ & Yes & $\begin{array}{l}\text { Men are more likely } \\
\text { to stay in a } \\
\text { leadership position } \\
\text { compared to } \\
\text { women, irrespective } \\
\text { of the gender } \\
\text { composition of the } \\
\text { respective } \\
\text { occupation held. }\end{array}$ & No \\
\hline $\mathrm{H} 2$ & $\begin{array}{l}\text { Men and women are } \\
\text { more likely to hold } \\
\text { a leadership position } \\
\text { in male-typical } \\
\text { occupations than in } \\
\text { female-typical ones. }\end{array}$ & Yes & $\begin{array}{l}\text { Men and women in } \\
\text { male-typical } \\
\text { occupations are } \\
\text { more likely to stay } \\
\text { in leadership } \\
\text { positions, } \\
\text { irrespective of } \\
\text { gender. }\end{array}$ & Yes \\
\hline H3 & $\begin{array}{l}\text { The male advantage } \\
\text { in entering a } \\
\text { leadership position } \\
\text { through } \\
\text { gender-typical } \\
\text { occupations is } \\
\text { greater than } \\
\text { gender-atypical } \\
\text { ones. }\end{array}$ & Yes & $\begin{array}{l}\text { The male advantage } \\
\text { in staying in a } \\
\text { leadership position } \\
\text { is higher in } \\
\text { gender-typical } \\
\text { occupations rather } \\
\text { than in } \\
\text { gender-atypical } \\
\text { occupations. }\end{array}$ & Yes \\
\hline $\mathrm{H} 4$ & $\begin{array}{l}\text { The male advantage } \\
\text { in entering a } \\
\text { leadership position } \\
\text { is highest in } \\
\text { gender-atypical } \\
\text { occupations rather } \\
\text { than gender-typical } \\
\text { ones. }\end{array}$ & $\begin{array}{l}\text { Yes, in form of } \\
\text { smaller disad- } \\
\text { vantage }\end{array}$ & $\begin{array}{l}\text { The male advantage } \\
\text { in staying in a } \\
\text { leadership position } \\
\text { is highest in } \\
\text { gender-atypical } \\
\text { occupations rather } \\
\text { than gender-typical } \\
\text { ones. }\end{array}$ & $\begin{array}{l}\text { Yes, in form of } \\
\text { smaller disad- } \\
\text { vantage }\end{array}$ \\
\hline
\end{tabular}

compared to women. Thus, we do not find any evidence of a glass escalator for men but an advantage compared to women in female occupations.

The second dimension of the comparable male advantage in upward occupational mobility refers to the revolving doors analogy, meaning wherein that individualsespecially women-who manage to enter a leadership position are forced out again. The findings from this analysis are perhaps the most surprising as the male advantage is not statistically significant (H1b). However, the expected gender composition effect is indeed evident: Men as well as women have the highest dropout risk in female occupations $(\mathrm{H} 2 \mathrm{~b})$ even if this disadvantage in female occupations is again less pronounced for men, so that $\mathrm{H} 3 \mathrm{~b}$ as well as $\mathrm{H} 4 \mathrm{~b}$ receives 
support from our results and are not thus competing as expected. There is no male advantage compared to women to stay in leadership position in male occupations.

The general conclusion from our results is that it is not appropriate to analyze gender differences in upward occupational mobility without taking into account the gender composition of occupations and especially the interaction effects. Furthermore, investigating only the access to leadership provides only limited insight into the male-advantage regarding leadership. While many studies have focused on gender differences in leadership access, we found only significant gender differences in terms of staying in leadership for female occupations.

Nevertheless, our results suggest that the (self-)selection into gender-typical occupations largely fosters a male advantage regarding access and lead to a gender difference in dropout risks out of leadership. The lower dropout risk for women in mixed and especially male occupations is likely to reflect a specific selection of women into leadership and into male occupations regarding other factors, such as personality or career-orientation. Unfortunately, we were not able to control for or analyze a probable mechanism of (self-)selection with our data. Therefore, further research is needed to assess results properly. The use of experiments is particularly promising to provide important insights into these mechanisms underlying gender differences and gender discrimination (Correll et al. 2007, see also).

Acknowledgements This paper uses data from the National Educational Panel Study (NEPS): Starting Cohort Adults, doi:10.5157/NEPS:SC6:5.1.0. From 2008 to 2013, NEPS data was collected as part of the Framework Program for the Promotion of Empirical Educational Research funded by the German Federal Ministry of Education and Research (BMBF). As of 2014, NEPS is carried out by the Leibniz Institute for Educational Trajectories (LIfBi) at the University of Bamberg in cooperation with a nationwide network.

\section{References}

Acker, J. (1990). Hierarchies, jobs, bodies: A theory of gendered organizations. Gender \& Society, 4(2), 139-158.

Aisenbrey, S., Evertsson, M., \& Grunow, D. (2009). Is there a career penalty for mothers' time out? a comparison of Germany, Sweden and the United States. Social Forces, 88(2), 573-605.

Andreß, H.-J., Golsch, K., \& Schmidt, A. W. (2013). Applied panel data analysis for economic and social surveys. Berlin/Heidelberg: Springer.

Baron, J. N., \& Newman, A. E. (1990). For what its worth: Organizations, occupations and the value of work done by women and non-whites. American Sociological Review, 55(2), 155-175.

Benard, S., \& Correll, S. J. (2010). Normative discrimination and the motherhood penalty. Gender \& Society, 24(5), 616-646.

Blossfeld, H.-P., Golsch, K., \& Rohwer, G. (2012). Event history analysis with Stata. Mahwah: Lawrence Erlbaum.

Blossfeld, H.-P., Roßbach, H.-G., \& von Maurice, J. (Eds.). (2011). Education as a lifelong process - The German National Educational Panel Study (NEPS) (Vol. 14). Sonderheft: Zeitschrift für Erziehungswissenschaft.

Bröckel, M., Busch-Heizmann, A., \& Golsch, K. (2015). Headwind or tailwind: Do partners' resources support or restrict promotion to a leadership position in Germany? European Sociological Review, 31(5), 533-545. 
Brückner, H. (2004). Gender inequality in the life course: Social change and stability in West Germany 1975-1995. New York: Aldine de Gruyter.

Budig, M. J. (2002). Male advantage and the gender composition of jobs: Who rides the glass escalator? Social Problems, 49(2), 258-277.

Budig, M. J., Misra, J., \& Boeckmann, I. (2012). The motherhood penalty in cross-national perspective: The importance of work-family policies and cultural attitudes. Social Politics, 19(2), 163-193.

Busch, A. (2013). Die berufliche Geschlechtersegregation in Deutschland: Ursachen, Reproduktion, Folgen. Wiesbaden: Springer VS.

Busch, A., \& Holst, E. (2009). Glass ceiling effect and earnings: The gender pay gap in managerial positions in Germany. DIW Discussion Papers 905, Berlin.

Charles, M. (2003). Deciphering sex segregation: Vertical and horizontal inequalities in ten national labor markets. Acta Sociologica, 46(4), 267-287.

Charles, M., \& Grusky, D. B. (2004). Occupational Ghettos: The worldwide segregation of women and man. Stanford, CA: Stanford University Press.

Cockburn, C. (1991). In the way of women: Men's resistance to sex equality in organizations (Cornell international industrial and labor relations report, Vol. 18). Ithaca: ILR Press.

Correll, S. J., Thébaud, S., \& Benard, S. (2007). An introduction to the social psychology of gender. In S. J. Correll (Ed.), Social psychology of gender (Advances in group processes, Vol. 24, pp. 118). Amsterdam: Emerald.

Cotter, D. A., Hermsen, J. M., Ovadia, S., \& Vanneman, R. (2001). The glass ceiling effect. Social Forces, 80(2), 655-681.

Dämmrich, J., \& Blossfeld, H.-P. (2017). Women's disadvantage in holding supervisory positions. variations among European countries and the role of horizontal gender segregation. Acta Sociologica, 60(3), 262-282.

Eagly, A. H. (2003). Few women at the top: How role incongruity produces prejudice and the glass ceiling. In D. van Knippenberg \& M. A. Hogg (Eds.), Leadership and power: Identity processes in groups and organizations (pp. 79-93). London: Sage Publications.

Eagly, A. H., \& Karau, S. J. (2002). Role congruity theory of prejudice toward female leaders. Psychological Review, 109(3), 573-598.

Edwards, R. (1979). Contested terrain: The transformation of the workplace in the twentieth century. New York: Basic Books.

Eisenmenger, M., Loos, C., \& Sedmihradsky, D. (2014). Erwerbstätigkeit in Deutschland Ergebnisse des Zensus 2011. WISTA Wirtschaft und Statistik, 9, 544-560.

England, P. (2005). Gender inequality in labor markets: The role of motherhood and segregation. Social Politics, 12(2), 264-288.

England, P., Herbert, M. S., Kilbourne, B. S., Reid, L. L., \& Megdal, L. M. (1994). The gendered valuation of occupations and skills: Earnings in 1980 census occupations. Social Forces, 73(1), $65-100$.

Farkas, G., \& England, P. (Eds.). (1988). Industries, firms, and jobs: Sociological and economic approaches. New York: Plenum Press.

Gangl, M., \& Ziefle, A. (2009). Motherhood, labor force behavior, and women's careers: An empirical assessment of the wage penalty for motherhood in Britain, Germany, and the United States. Demography, 46(2), 341-369.

Härkönen, J., Manzoni, A., \& Bihagen, E. (2016). Gender inequalities in occupational prestige across the working life: An analysis of the careers of West Germans and Swedes born from the 1920s to the 1970s. Advances in Life Course Research, 29, 41-51.

Holst, E. (2006). Women in managerial positions in Europe: Focus on Germany. Management revue, $17(2), 122-142$.

Hultin, M. (2003). Some take the glass escalator, some hit the glass ceiling: Career consequences of occupational sex segregation. Work and Occupations, 30(1), 30-61.

Jacob, M., Kleinert, C., \& Kühhirt, M. (2013). Trends in gender disparities at the transition from school to work: Labour market entries of young men and women between 1984 and 2005 in West Germany. Journal of Vocational Education \& Training, 65(1), 48-65. 
Jacobs, J. A. (1989). Revolving doors: Sex segregation and women's careers. Stanford, CA: Stanford University Press.

Kanter, R. M. (1977). Men and women of the corporation. New York: Basic Books.

Ko, I., Kotrba, L., \& Roebuck, A. (2015). Leaders as males? The role of industry gender composition. Sex Roles, 72(7-8), 294-307.

Lindemann, K., \& Kogan, I. (2013). The role of language resources in labour market entry: Comparing Estonia and Ukraine. Journal of Ethnic and Migration Studies, 39(1), 105-123.

Manzoni, A., Harkonen, J., \& Mayer, K. U. (2014). Moving on? a growth-curve analysis of occupational attainment and career progression patterns in West Germany. Social Forces, 92(4), $1285-1312$.

Maume, D. J. (1999a). Glass ceilings and glass escalators: Occupational segregation and race and sex differences in managerial promotions. Work and Occupations, 26(4), 483-509.

Maume, D. J. (1999b). Occupational segregation and the career mobility of white men and women. Social Forces, 77(4), 1433-1459.

Ochsenfeld, F. (2012). Gläserne Decke oder goldener Käfig: Scheitert der Aufstieg von Frauen in erste Managementpositionen an betrieblicher Diskriminierung oder an familiären Pflichten? Kölner Zeitschrift für Soziologie und Sozialpsychologie, 64(3), 507-534.

Reskin, B. (1988). Bringing the men back in: Sex differentiation and the devaluation of women's work. Gender \& Society, 2(1), 58-81.

Reskin, B. (1993). Sex segregation in the workplace. Annual Review of Sociology, 19(1), 241-270.

Reskin, B., \& Roos, P. (1990). Job queues, gender queues: Explaining women's inroads into male occupations (Women in the political economy). Philadelphia: Temple University Press.

Ridgeway, C. L. (2001). Gender, status, and leadership. Journal of Social Issues, 57(4), 637-655.

Ridgeway, C. L., \& Correll, S. J. (2004). Unpacking the gender system: A theoretical perspective on gender beliefs and social relations. Gender \& Society, 18(4), 510-531.

Sengenberger, W. (1987). Struktur und Funktionsweise von Arbeitsmärkten: Die Bundesrepublik Deutschland im internationalen Vergleich. Arbeiten aus dem Institut für Sozialwissenschaftliche Forschung e. V. ISF München. Frankfurt/Main: Campus-Verl.

Smyth, E. (2005). Gender differentiation and early labour market integration across Europe. European Societies, 7(3), 451-479.

Sørensen, A. B., \& Kalleberg, A. L. (1981). An outline of a theory of the matching of persons to jobs. In I. E. Berg (Ed.), Sociological perspectives on labor markets (Quantitative studies in social relations, pp. 49-74). New York: Academic.

Trappe, H., Pollmann-Schult, M., \& Schmitt, C. (2015). The rise and decline of the male breadwinner model: Institutional underpinnings and future expectations. European Sociological Review, 31(2), 230-242.

Williams, C. L. (1992). The glass escalator: Hidden advantages for men in the 'female' professions. Social Problems, 39(3), 253-267.

Williams, C. L. (2013). The glass escalator, revisited. Gender \& Society, 27(5), 609-629.

Open Access This chapter is licensed under the terms of the Creative Commons Attribution 4.0 International License (http://creativecommons.org/licenses/by/4.0/), which permits use, sharing, adaptation, distribution and reproduction in any medium or format, as long as you give appropriate credit to the original author(s) and the source, provide a link to the Creative Commons license and indicate if changes were made.

The images or other third party material in this chapter are included in the chapter's Creative Commons license, unless indicated otherwise in a credit line to the material. If material is not included in the chapter's Creative Commons license and your intended use is not permitted by statutory regulation or exceeds the permitted use, you will need to obtain permission directly from the copyright holder.

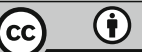

